\title{
Article/Artigo
}

\section{Molecular analysis and dimorphism of azole-susceptible and resistant Candida albicans isolates}

\author{
Análise molecular e dimorfismo de isolados de Candida albicans suscetíveis e resistentes aos azólicos
}

\section{Carolina Rodrigues Costa ${ }^{1}$, Lúcia Kioko Hasimoto e Souza ${ }^{1}$, Fábio Silvestre Ataídes ${ }^{1}$, Pedro Henrique Ferri ${ }^{2}$, Maysa Paula da Costa ${ }^{1}$, Orionalda de Fátima Lisboa Fernanades ${ }^{1}$ and Maria do Rosário Rodrigues Silva ${ }^{1}$}

\begin{abstract}
Introduction: Candida albicans is responsible for superficial or systemic infections known as candidiasis, which may be found in infected tissue as unicellular budding yeasts, hyphae, or pseudohyphae. In this study, the effects of both fluconazole and itraconazole antifungal agents on the hyphal formation and genotypic characterization of C. albicans isolates classified as either susceptible or resistant were investigated. Methods: The hyphal production of five C. albicans isolates under the action of antifungal agents was investigated by culturing yeast on growth medium and on hyphal induction medium. The genotypic characterization was carried out for 13 isolates of $C$. albicans using the random amplified polymorphic DNA-polymerase chain reaction (RAPD-PCR) method. Results: The dimorphism analysis showed that the hyphal formation was higher in resistant than in the susceptible isolates to both azoles. The RAPD-PCR method identified the formation of two different groups. In group A, four resistant and two susceptible isolates were clustered, and in group B, one resistant and six susceptible isolates were clustered. Conclusions: Considering that hyphal formation was higher in resistant isolates in the presence of azole drugs, we confirmed that the hyphal production is closely related to susceptibility to azoles. These drugs may affect the morphogenesis of $C$. albicans depending on their susceptibility to these drugs. In relation to RAPD-PCR, most resistant isolates classified in group A and susceptible isolates in group B demonstrated that this method presented a similar standard between the two groups, suggesting that by this technique, a strong correlation between genotypes and fluconazole-resistant samples may be found.
\end{abstract}

Keywords: Candida albicans. Azole antifungals. Hyphal formation. In vitro susceptibility. RAPD-PCR

\section{RESUMO}

Introdução: Candida albicans é responsável por infecções superficiais ou sistêmicas conhecidas como candidíase, encontrada em tecidos infectados na forma de leveduras brotantes unicelulares, hifas ou pseudohifas. Neste estudo, os efeitos de agentes antifúngicos como o fluconazol e o itraconazol sobre a formação de hifas e caracterização genotípica de isolados de C. albicans suscetíveis ou resistentes foram investigados. Métodos: A produção de hifas de cinco isolados de C. albicans, sob a ação de antifúngicos foi investigada pelo cultivo da levedura em meios de crescimento e de indução de hifas. A caracterização genotípica foi realizada para 13 isolados de C. albicans pelo método de RAPD-PCR. Resultados: A análise do dimorfismo mostrou que a formação de hifas foi maior nos isolados resistentes do que nos suscetíveis aos antifúngicos. $\mathrm{O}$ método de RAPD-PCR identificou a formação de dois diferentes grupos. No grupo A, foram agrupados quatro isolados resistentes e dois suscetíveis e no grupo $\mathrm{B}$ um resistente e seis suscetíveis. Conclusões: Considerando que a formação hifal foi maior em isolados resistentes na presença de azólicos, concluimos que a produção hifal está muito relacionada a suscetibilidade a estes fámacos. Estes antifúngicos podem alterar a morfologia de C. albicans em dependência da sua suscetibilidade. No método de RAPD-PCR, o encontro da maioria dos isolados resistentes classificados como pertencentes ao grupo A e suscetíveis ao grupo B demonstrou que este método apresentou um padrão semelhante entre os dois grupos, sugerindo que por este método pode ser detectado uma estreita correlação entre genótipos e amostras resistentes ao fluconazol.

Palavras-chaves: Candida albicans. Antifúngicos azólicos. Formação hifal. Suscetibilidade in vitro. RAPD-PCR.

1. Instituto de Patologia Tropical e Saúde Pública, Universidade Federal de Goiás, Goiânia, GO. 2.Instituto de Química, Universidade Federal de Goiás, Goiânia, GO.

Address to: Dra. Maria do Rosário Rodrigues Silva. IPTSP/UFG. Rua 235 s/n, Setor Universitário, 74605-050 Goiânia, GO, Brasil.

Phone: 5562 3209-6127; Fax 5562 3209-6363.

e-mail: rosario.iptsp@ufg.br

Received in $12 / 05 / 2011$

Accepted in 16/06/2011

\section{INTRODUCTION}

Candida albicans is responsible for superficial or systemic infections known as candidiasis, which is frequently associated with immunocompromised patients ${ }^{1}$. It may be found in infected tissue as unicellular buddingyeasts, hyphae, or pseudohyphae. The dimorphism facilitates tissue invasion, increases tissue viability, and allows it to escape from macrophage and neutrophil engulfment ${ }^{2,3}$.

Some antifungal agents affect the morphology of C. albicans cells. According to Gil et al. ${ }^{4}$, hyphal forms are predominant in azole-resistant isolates. Hyphal formation in susceptible strains is inhibited at clinically significant concentrations of azole drugs. ${ }^{5}$

Genetic analysis of Candida isolates reveals that virulence attributes may be intimately related to genotypic profiles. Molecular methods have been used for such analysis because of their sensitivity and specificity, allowing intraspecific identification of isolates as well as detection of small differences in nucleic acid content among species and ancestries of the same species ${ }^{6}$. The analysis of the random amplified polymorphic DNA (RAPD) is used for characterization of fungi, especially C. albicans ${ }^{7}$. This technique presents speed, simplicity, and power discriminatory among the isolated ones ${ }^{6,8}$.

Evidence shows that azole-resistant isolates, especially fluconazole, result from genomic alterations ${ }^{9,10}$. The emergence of fluconazole resistance may be associated with continued exposure of C. albicans population to this drug, leading to a gradual elevation of minimal inhibitory concentration (MIC) of some isolates $^{9-11}$. However, there is little information about the genomic diversity of resistant isolates to antifungals compared with those that are susceptible to the drugs.

Thus, this study investigates C. albicans hyphal formation of susceptible and resistant isolates in the presence of azole drugs and genotypically characterizes fluconazole-susceptible and -resistant isolates. 


\section{METHODS}

\section{Candida albicans identification}

Candida albicans isolates from oral cavities of human immunodeficiency virus (HIV)-infected patients used in this study were previously identified using germ tube test, chlamidoconidia formation, carbon and nitrogen assimilation, and sugar fermentation ${ }^{12}$. Furthermore, all isolates were streaked onto CHROMagar® Candida medium plates (CHROMagar, Paris, France) for presumptive identification of C. albicans. API 20 Candidaidentification kit (BioMerieux, France) was used when the yeasts could not be identified by any of the methods previously mentioned. Growth at $45^{\circ} \mathrm{C}$ on Sabouraud dextrose broth and assimilation tests with xylose and $\alpha$-methyl-D-glucoside were used for discrimination between C. albicans and Candida dubliniensis ${ }^{13,14}$. All isolates were stored at $-70^{\circ} \mathrm{C}$ in yeast extract peptone dextrose agar (YEPD-Difco) with 10\% glycerol and subcultured twice on YEPD agar before testing to ensure purity of cultures.

\section{In vitro antifungal susceptibility testing}

Minimal inhibitory concentrations were determined using broth microdilution method in RPMI 1640 medium, standardized by Clinical and Laboratory Standards Institute (CLSI) ${ }^{15}$.

\section{Antifungal agents}

Itraconazole and fluconazole were tested against 13 C. albicans isolates. The final concentration of drugs ranged from 0.06 to $64 \mu \mathrm{g} / \mathrm{ml}$ for fluconazole and from 0.015 to $16 \mu \mathrm{g} / \mathrm{ml}$ for itraconazole. In vitro susceptibility tests were performed to yield eight times the final concentration when the MICs were $>64 \mu \mathrm{g} / \mathrm{ml}$ for fluconazole and $>16 \mu \mathrm{g} / \mathrm{ml}$ for itraconazole. Candida parapsilosis ATCC 22019 was included as a quality control strain to check the accuracy of drug dilutions and reproducibility of results.

\section{Determination of resistance}

Candida albicans isolates were considered resistant when MIC values were $\geq 64 \mu \mathrm{g} / \mathrm{ml}$ for fluconazole and $\geq 1 \mu \mathrm{g} / \mathrm{ml}$ for itraconazole, according to breakpoints established by CLSI ${ }^{15}$.

\section{Dimorphism of azole-resistant and -susceptible strains}

To determine the effects of azole antifungal agents on hyphal production, five isolates of $C$. albicans classified as susceptible (numbers 2, 8, and 15) and resistant (numbers 13 and 23) to both azoles were used.

\section{Yeast growth and hyphal induction in}

\section{the presence of itraconazole or fluconazole}

Hyphal induction under the action of antifungal agents was performed according to $\mathrm{Ha}$ and White ${ }^{5}$ with slight modifications. Briefly, the isolates stored at $-70^{\circ} \mathrm{C}$ in YEPD medium were subcultured in an agar plate of this medium for $24 \mathrm{~h}$. Single yeast colonies were inoculated in $5 \mathrm{ml}$ of YAD medium $(1.7 \mathrm{~g}$ of yeast nitrogen base without amino acids and ammonium sulfate, $5 \mathrm{~g}$ of ammonium sulfate, and $5.4 \mathrm{~g}$ of dextrose per liter) for $48 \mathrm{~h}$ in the presence of different concentrations of fluconazole or itraconazole $(1 / 2,1 / 4$, and $1 \times \mathrm{MIC})$ as well as in the absence of these drugs.

After incubation with shaking $(180 \mathrm{rpm})$ at $30^{\circ} \mathrm{C}$, cell cultures were centrifuged for $5 \mathrm{~min}$ at $10^{\circ} \mathrm{C}$, washed twice with $5 \mathrm{ml}$ of phosphate-buffered saline, and then transferred to $5 \mathrm{ml}$ of hyphal induction medium (M199) containing bovine calf serum (10\%) to a final concentration of $3 \times 10^{6}$ cells $/ \mathrm{ml}$. The same concentrations of antifungal agents $(0,1 / 2,1 / 4$, and $1 \times \mathrm{MIC})$ were added to the hyphal induction medium. Cells were incubated at $37^{\circ} \mathrm{C}$ with shaking at 240rpm. After $3 \mathrm{~h}, 250$ cells (yeast and hyphae) were counted using the Neubauer chamber. These experiments were repeated in two different occasions, and the mean was calculated.

\section{Genotypic characterization}

A total of 13 C. albicans isolates characterized as susceptible or resistant to fluconazole were submitted to genotypic identification using the RAPD-PCR technique.

\section{Preparation of DNA}

Genomic DNA extraction was based on the method described by Del Poeta et $\mathrm{al}^{16}$. and modified by Casali et $\mathrm{al}^{17}$. Briefly, a heavy inoculum of C. albicans strains grown in YEPD agar at $37^{\circ} \mathrm{C}$ for 24 to $48 \mathrm{~h}$ was suspended in $0.5 \mathrm{ml}$ of TENTS ( $10 \mathrm{mM}$ of Tris, $\mathrm{pH} 7.5$; $1 \mathrm{mM}$ of EDTA, pH $8.0 ; 200 \mathrm{mM}$ of $\mathrm{NaCl} ; 2 \%$ Triton; $1 \%$ SDS), containing $0.2 \mathrm{ml}$ of $0.45-\mathrm{mm}$ glass beads and $0.5 \mathrm{ml}$ of phenolchloroform, which were vortexed for $2 \mathrm{~min}$. After centrifugation for $10 \mathrm{~min}$ at $13,000 \mathrm{rpm}$, the aqueous phase was transferred to a new tube, and the same volume of ethanol (100\%) was added. It was then incubated at $-20^{\circ} \mathrm{C}$ for $1 \mathrm{~h}$ for DNA precipitation. The precipitated DNA was resuspended in $0.5 \mathrm{ml} \mathrm{TE}(10 \mathrm{mM}$ of Tris $\mathrm{HCl}, \mathrm{pH} 8.0$; $1 \mathrm{mM}$ of EDTA, $\mathrm{pH} 8.0$ ), containing $50 \mu \mathrm{g} / \mathrm{ml}$ of RNAse, and was incubated at $37^{\circ} \mathrm{C}$ for $30 \mathrm{~min}$. The yeast DNA was extracted once with phenol and chloroform, reprecipitated with $20 \mu \mathrm{l}$ of $\mathrm{NaCl}$ ( $5 \mathrm{~mol} / \mathrm{l})$ and 1 volume of $100 \%$ ethanol, washed with $70 \%$ ethanol, resuspended in $100 \mu \mathrm{l}$ of TE buffer, and stored at $-20^{\circ} \mathrm{C}$.

\section{Random amplified polymorphic DNA analysis}

Amplification reactions using primer RSD6 (5'-GCGATCCCCA-3') were performed as described by Dassanayake et al ${ }^{18}$. The reactions were performed in volume of $25 \mu \mathrm{l}$, including about $50 \mathrm{ng}$ of DNA template, $10 \mathrm{mM}$ of Tris- $\mathrm{HCl}, \mathrm{pH} 8.3(2.5 \mu \mathrm{l})$, $50 \mathrm{mM}$ of $\mathrm{KCl}(1 \mu \mathrm{l}), 1.5 \mathrm{mM}$ of $\mathrm{MgCl}_{2}, 0.2 \mathrm{mM}$ of each dNTP $(2 \mu \mathrm{l})$, and $2.5 \mathrm{U}(0.5 \mu \mathrm{l})$ of Taq DNA polymerase (Invitrogen), added with $1.5 \mu \mathrm{M}$ of RSD6 (1.25 $\mathrm{l})$. Amplification was performed in a PCR MJ Research Thermal Cycler model PTC- $100^{\mathrm{TM}}$ programmed as follows: The first five cycles included denaturation at $94^{\circ} \mathrm{C}$ for $30 \mathrm{~s}$, annealing at $27^{\circ} \mathrm{C}$ for $2 \mathrm{~min}$, and primer extension at $72^{\circ} \mathrm{C}$ for 2 min, followed by 45 denaturation cycles at $94^{\circ} \mathrm{C}$ for 30 s, annealing at $32^{\circ} \mathrm{C}$ for $2 \mathrm{~min}$, and a final extension at $72^{\circ} \mathrm{C}$ for $2 \mathrm{~min}$, held at this temperature for $15 \mathrm{~min}$. Amplification products were separated using electrophoresis in $1.2 \%$ agarose gel containing $1 \mathrm{X}$ Tris-borate-EDTA buffer, stained with blue green (LGC Biotechnology) and visualized under UV light.

\section{Statistical analysis}

The results obtained on dimorphism were analyzed by a proportion test using the Epi-info version 6.0. $p$ values $<0.05$ were considered statistically significant. The dendrogram of the genetic similarity of fluconazole-susceptible and resistant isolates was performed by PAST version $1.91^{19}$ via the unweighed pair-group average method (UPGMA), using the Raup-Crick similarity index ${ }^{20}$. Cophenetic correlation was used to check the representativeness of the clustering procedure ${ }^{21}$.

\section{Ethical considerations}

This study was approved by the Bioethics Committee of Hospital de Doenças Tropicais de Goiás (protocol 007/2004) and Hospital das Clínicas of Universidade Federal de Goiás (protocol 027/07). 


\section{RESULTS}

\section{Susceptibility testing}

According to the interpretive criteria used for antifungal drug resistance described in the Materials and Methods section, five resistant and eight susceptible $C$. albicans isolates for each one of the drugs were identified. Fluconazole MIC values were $64 \mu \mathrm{g} / \mathrm{ml}$ in one isolate (34), $128 \mu \mathrm{g} / \mathrm{ml}$ in four $(1,13,23$, and 24$)$, and $\leq 4 \mu \mathrm{g} /$ $\mathrm{ml}$ for the other eight. Itraconazole MIC values were $64 \mu \mathrm{g} / \mathrm{ml}$ in two isolates (13 and 23), $16 \mu \mathrm{g} / \mathrm{ml}$ in three $(5,36$, and 115$)$, and $\leq 0.5 \mu \mathrm{g} / \mathrm{ml}$ for the other eight. Antifungal susceptibility of C. parapsilosis ATCC 22019 was within the ranges previously reported.

\section{Dimorphism}

Among the five $C$. albicans isolates analyzed, differences at the hyphal formation because of concentration of antifungal drugs and azole susceptibility were observed. In all isolates, the reduction of hyphal formation was directly related to drug concentration. There was a higher reduction of hyphae in $1 \times$ MIC values than in $1 / 2$ MIC and 1/4 MIC values. For susceptible isolates, a statistically significant difference was observed between $1 \times \mathrm{MIC}$ and $1 / 2 \mathrm{MIC}$, and between $1 \times \mathrm{MIC}$ and $1 / 4 \mathrm{MIC}(\mathrm{p}<0.001)$, but not between $1 / 2$ MIC and 1/4 MIC.

For the resistant isolates, statistical difference in relation to the reduction of hyphae between the MIC values tested was not observed. In the absence of antifungal drugs (control), more than $90 \%$ of hyphal formation was observed in all susceptible or resistant isolates.

The hyphal formation also varied according to the drug; it was more susceptible to inhibition by itraconazole than fluconazole. For instance, in one isolate (13), hyphae formation reached $28.8 \%$ under the effect of itraconazole $1 \times$ MIC, whereas it reached $50 \%$ with fluconazole under similar conditions. Nevertheless, there was no statistically significant difference between the two antifungal agents.

Hyphal formation was higher in resistant isolates in the presence of azole drugs $(p<0.001)$. Figures 1 and $\mathbf{2}$ show the hyphal production by susceptible and resistant isolates induced by incubation with both fluconazole and itraconazole MICs and subMICs.

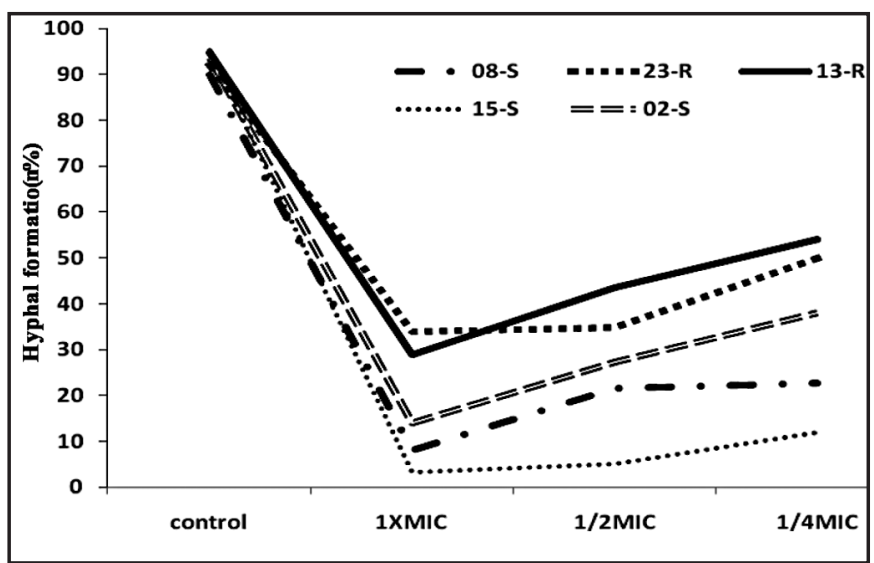

FIGURE 1 - Effects of different concentrations of itraconazole (1xMIC, 1/2 and 1/4 MIC, and control = absence of drug) on hyphal formation (M199 medium added with $10 \%$ bovine calf serum) in both susceptible $(2,8$, and 15$)$ and resistant (13 and 23) Candida albicans isolates.

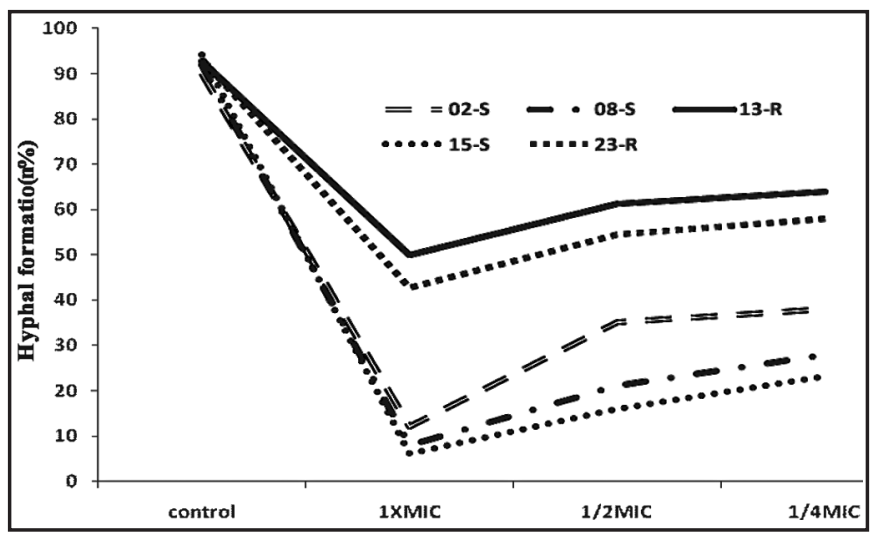

FIGURE 2 - Effects of different concentrations of fluconazole (1xMIC, $1 / 2$ and 1/4 MIC, and control = absence of drug) on hyphal formation (M199 medium added with $10 \%$ bovine calf serum) in both susceptible (2,8, and 15$)$ and resistant (13 and 23) Candida albicans isolates.

Genotypic characterization of fluconazole-resistant and -susceptible C. albicans isolates using RAPD-PCR

Candida albicans isolates showed a number of bands ranging from seven to 11 using primer RSD6 by the RAPD-PCR method (Figure 3). Data interpretation criteria were related to differences in position of the bands. The generated profile of the bands allowed the identification of eight different genotypes among the 13 C. albicans isolates - fluconazole-resistant or -susceptible. They were classified as groups $\mathrm{A}$ and $\mathrm{B}$ in agreement with the dendrogram of genetic similarity using the Raup-Crick coefficient index, a probabilistic measure based on presence-absence data. The UPGMA had a high cophenetic correlation of 0.86 , suggesting that the dendrogram preserves the pairwise distances between the original unmodeled data points. Group A included susceptible isolates 15 and 36 and resistant isolates 1, 23, 24, and 34. Group B included susceptible isolates $2,5,12,55$, and 115 and resistant isolate 13 , as it is shown in Figure 4. Three $(1,23$, and 34) of the five fluconazole-resistant isolates produced the same genotypic profile (A1). However, only two (2 and 5) produced the same genotypic profile (B1) among fluconazole-susceptible isolates. Fluconazole-susceptible isolates, 15 and 36, presented the same genotypic profile as the resistant isolates, classified as A1. The other isolates produced independent genotypes. The molecular profiles of isolates are shown in Table $\mathbf{1 .}$

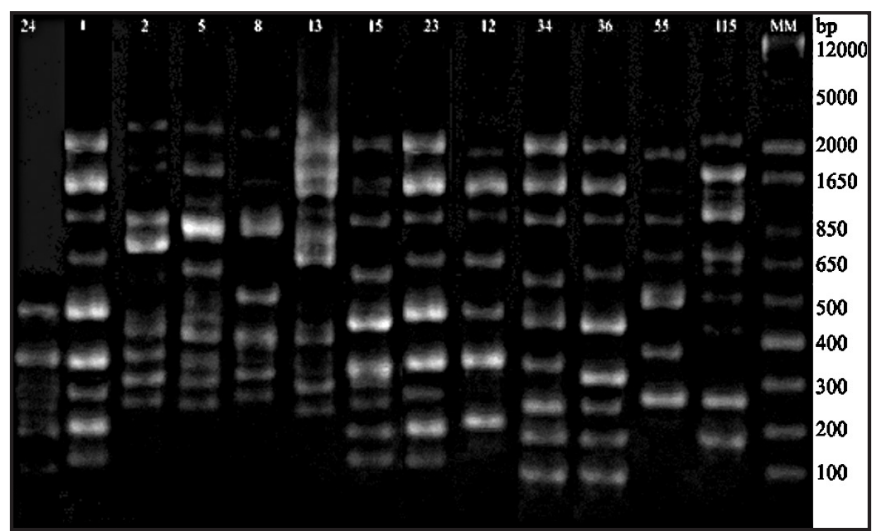

FIGURE 3 - Random amplified polymorphic DNA fingerprinting of fluconazolesusceptible Candida albicans isolates $(2,5,8,12,15,36,55$, and 115) and fluconazole-resistant isolates $(1,13,23,24$, and 34) obtained using primer RSD6. MM: marker of 100 base pairs (Invitrogen). 


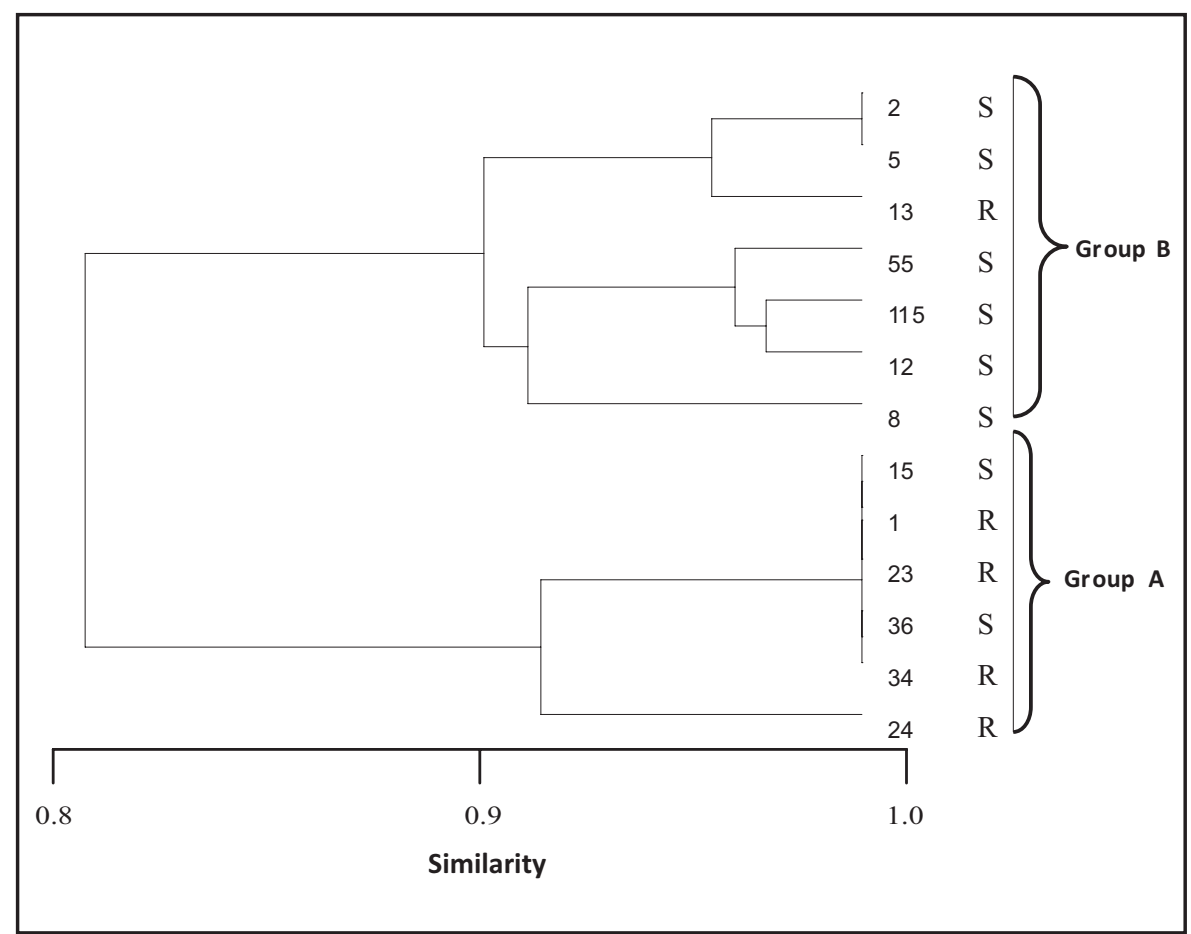

FIGURE 4 - Dendrogram of 13 fluconazole-resistant Candida albicans isolates (1, 13, 23, 24, and 34) and fluconazole-susceptible isolates $(2,5,8,12,15,36,55$, and 115$)$ obtained by amplification using primer RSD6. in vitro adhesion - initial phase for penetration of a microorganism — to buccal epithelial cells than filamentous forms ${ }^{1}$.

The influence of azole antifungals related to the ability of fungi to form hyphae by susceptible or resistant isolates to these antifungal has been little investigated. There are indications that fluconazole-susceptible yeasts present reduced hyphae production, whereas resistant isolates have been little affected by this antifungal agent ${ }^{5}$. In this study, inhibition of hyphal growth of azolesusceptible strains of $C$. albicans was observed at higher levels than resistant isolates in the presence of both itraconazole and/ or fluconazole. Such inhibition depended on antifungal concentration. Interestingly, growth inhibition in susceptible isolates was accompanied by reduction of hyphal formation. This result allowed suggesting that no inhibition of growth of the fungi under the effects of the antifungal in resistant isolates presents a strong correlation with the filamentous production. It is known that azoles act by inhibiting production of
TABLE 1 - Molecular profile by RAPD method of resistant and susceptible Candida albicans isolates to fluconazole.

\begin{tabular}{lcc}
\hline & Isolates & Molecular profile \\
\hline \multirow{3}{*}{ Resistant } & 1 & A1 \\
& 13 & B2 \\
& 23 & A1 \\
& 24 & A2 \\
Susceptible & 34 & A1 \\
& 2 & B1 \\
& 5 & B1 \\
& 8 & B6 \\
& 12 & B5 \\
& 15 & A1 \\
& 36 & A1 \\
\hline
\end{tabular}

\section{DISCUSSION}

Exoenzyme production, adherence ability of host cells, the ability to produce hyphae, and antifungal drug resistance are considered important virulence factors of Candida species, which facilitate the establishment of infection ${ }^{22,23}$.

The transition from spherical cells to hyphae expressed by C. albicans is strictly related to yeast pathogenicity. Filamentous fungi have a structure that allows penetration into the host tissue more easily than spherical cell forms ${ }^{23,24}$. Enzymes are mainly secreted from hyphae tips and are able to degrade proteins, lipids, and other cellular components that facilitate tissue infiltration ${ }^{25}$. Mutant yeasts are unable to form filaments, thus presenting reduced invasion capacity and virulence in mouse models ${ }^{23,26}$. Spherical cells show less ergosterol, which is the main constituent of a fungal cell membrane. These antifungal agents probably reduce the production of hyphae because of the increased surface area of hyphal cells in comparison to those of spherical forms. The hyphal structure requires more plasma membrane to the cell. Previous works show that alterations in the ERG11 gene, responsible for ergosterol production, limit hyphal formation presumably because of the lack of ergostero ${ }^{27}$. Although fluconazole is the most used antifungal agent for the treatment of infections caused by $C$. albicans, an increased number of resistant isolates have been observed ${ }^{18}$. Therefore, detection of resistance among isolates is considered of great importance.

Yeast genotypes may vary according to drug susceptibility. The genetic diversity among fluconazole-resistant $C$. albicans isolates has revealed controversial results. Genotypic characterization in groups has been defined by Xu et al. ${ }^{28}$ for resistant isolates to fluconazole, who observed that resistant strains to this drug were genetically more similar to each other than they were to susceptible strains. Dassanayake et al. ${ }^{18}$ showed that, of the 20 isolates studied, only one resistant isolate presented the same profile as the susceptible one.

The molecular profile found in this work using the primer RSD6 by RAPD-PCR, with eight different genotypes being four of the five resistant isolates to the fluconazole classified in the same group (A), showing the same original clonal and one isolate in another group (B) shared with susceptible isolates, proved that the behaviors of the resistant strains were similar but may also be another clonal source. In a previous experiment with primer RSD6, 15 different genotypes were identified in 20 isolates, showing independent genotypes for each one of the 10 fluconazole-susceptible isolates but only six genotypes for the 10 fluconazole-resistant isolates ${ }^{18}$.

In conclusion, considering that hyphal formation was higher in resistant isolates in the presence of azole drugs, we confirmed that the hyphal production is closely related to susceptibility to azoles. According to $\mathrm{Ha}$ and White ${ }^{5}$, the azoles may affect the morphogenesis 
of C. albicans depending on their susceptibility to these drugs. Most resistant isolates classified in group A and susceptible isolates in group $\mathrm{B}$ demonstrated that RAPD-PCR typing method presented a similar standard between the two groups, suggesting that, by this technique, a strong correlation between genotypes and fluconazole-resistant samples may be found.

\section{CONFLICT OF INTEREST}

The authors declare that there is no conflict of interest.

\section{FINANCIAL SUPPORT}

Conselho Nacional de Desenvolvimento Científico e Tecnológico (CNPq). Process number 474837/2006-8.

\section{REFERENCES}

1. Kriznik A, Bouillot M, Coulon J, Gaboriaud F. Morphological specificity of yeast and filamentous Candida albicans forms on surface properties. Biologies 2005 ; 328:928-935.

2. Braga PC, Alfieri M, Culici M, Dal Dasso M. Inhibitory activity of thymol against the formation and viability of Candida albicans hyphae. Mycoses 2007; 50:502-506

3. Watamoto T, Samaranayake LP, Jayatilake JAMS, Egusa H, Yatani H, Seneviratne CJ. Effect of filamentation and mode of growth on antifungal susceptibility of Candida albicans. Int J Antimicrob Agents 2009; 34:333-339.

4. Gil C, Perez-Diaz R, Nombela C. Inhibitory and morphological effects of several antifungal agents on three types of C. albicans morphological mutants. J Med Vet Mycol 1994; 32:151-162.

5. Ha KC, White TC. Effects of azole antifungal drugs on the transition from yeast cells to hyphae in susceptible and resistant isolates of the pathogenic yeast Candida albicans. Antimicrob Agents Chemother 1999; 43:763-768.

6. Enache-Soare S, Pelinescu D, Ionescu R, Avram I, Stoica I, Vassu-Dimov T. Molecular identification of some yeast strains involved in oral candidosis. Rom Biotechnol Lett 2009; 14:4180-4186.

7. Boriollo MFG, Hofling JF, Mendes A, Rosa EAR. Ferramentas moleculares para caracterização de Candida albicans (Robin) Berkhout (1923) em estudos epidemiológicos. Est Biol 2005; 27:21-47.

8. Soll DR. The ins and outs of DNA fingerprinting the infectious fungi. Clin Microbiol Rev 2000; 13:332-370.

9. Franz R, Kelly SL, Lamb DC, Kelly DE, Ruhnke M, Morschhauser J. Multiple molecular mechanisms contribute to a stepwise development of fluconazole resistance in clinical Candida albicans strains. Antimicrob Agents Chemother 1998; 42:3065-3072.

10. Ribeiro MA, Paula CR, Perfect JR, Cox GM. Phenotypic and genotypic evaluation of fluconazole resistance in vaginal Candida strains isolated from HIV-infected women from Brazil. Med Mycol 2005; 43: 647-650.

11. Barchiesi F, Hollis RJ, McGough DA, Scalise G, Rinaldi MG, Pfaller MA. DNA subtypes and fluconazole susceptibilities of Candida albicans isolates from the oral cavities of patients with AIDS. Clin Inf Dis 1995; 20:634-640.

12. Kurtzman CP, Fell JW. The Yeasts, A Taxonomic Study. $4^{\text {th }}$ edition. Amsterdam, The Netherlands: Elsevier Science BV; 1998.

13. Dolapacci I, Tekeli A, Gocmen JS, Aysev D, Guriz H. Investigation of Candida dubliniensis in Candida spp.-positive hemocultures. Acta Path Microbial Scand 2002; 110:391-395.

14. Faggi E, Pini G, Campisi E, Martinelli C, Difonzo E. Detection of Candida dubliniensis in oropharyngeal samples from human immunodeficiency virus infected and non-infected patients and in a yeast culture collection. Mycoses 2005 ; 48:211-215.

15. Clinical and Laboratory Standards Institute. Reference Method for Broth Dilution Antifungal Susceptibility Testing of Yeasts, Approved Standard. CLSI document M27-A3. Third edition. Wayne, PA. CLSI 2008; 28:1-25.
16. Del Poeta M, Toffalettim DL, Rude TH, Dykstra CC, Heitman J, Perfect JR. Topoisomerase I is essential in Cryptococcus neoformans: role in pathology and as an antifungal target. Genetics 1999; 152:176-178.

17. Casali AK, Goulart L, Silva LKR, Ribeiro AM, Amaral AA, Alves SH, et al. Molecular typing of clinical and environmental Cryptococcus neoformans isolates in the Brazilian state Rio Grande do Sul. FEMS Yeast Res 2003; 33:405-415.

18. Dassanayake RS, Ellepola ANB, Samaranayake YH, Samaranayake LP. Molecular heterogeneity of fluconazole-resistant and susceptible oral Candida albicans isolates within a single geographic locale. APMIS 2002; 110:315-321.

19. Hammer O, Harper DAT, Ryan PD. PAST: Paleontological Statistics Software Package for Education and Data Analysis. Palaeontologia Electronica [Internet]. Version 2.10; 2001. Available from: http://folk.uio.no/ohammer/past 2009.

20. Harper DAT. Numerical Palaeobiology. Computer-Based Modelling and Analysis of Fossils and their Distributions. Media CD, version: 1.11. John Wiley \& Sons; 1999.

21. Sokal RR, Rohlf FJ. The comparison of dendrograms by objective methods. Taxon 1962; 11:33-40.

22. Calderone RA, Fonzi WA. Virulence factors of Candida albicans. Trend Microb 2001; 9:327-335

23. Yang YL. Virulence factors of Candida species. J Microbiol Immunol Infect $2003 ; 36: 223-228$.

24. Gow NAR, Brown AJP, Odds FC. Fungal morphogenesis and host invasion. Curr Opin Microbiol 2002; 5:366-371.

25. Hube B, Naglik J. Candida albicans proteinases: resolving the mystery of a gene family. Microbiology 2001; 147:1997-2005.

26. Felk A, Kretschmar M, Albrecht A, Schaller M, Beinhauer S, Nichterlein T, et al. Candida albicans hyphal formation and the expression of the Efg1-Regulated proteinases Sap4 to Sap6 are required for the invasion of parenchymal organs. Infect Immun 2002; 70:3689-3700.

27. Lees ND, Broughton MC, Sanglard D, Bard M. Azole susceptibility and hyphal formation in cytochrome P-450-deficient mutant of Candida albicans. Antimicrob Agents Chemother 1990; 34:831-836.

28. Xu J, Ramos AR, Vilgalys R, Mitchell TG. Clonal and spontaneous origins of fluconazole resistance in Candida albicans. J. Clin Microbiol 2000; 38:1214-1220. 